\title{
Legionellabakterier i vanninstallasjoner
}

Legionellose ble første gang beskrevet etter at 221 amerikanske legionærer ble syke etter å ha feiret 200-årsjubileum på et hotell i Philadelphia i 1976. Det skulle gå 25 år før Norge fikk sitt første utbrudd. I 2001 ble 28 mennesker smittet i Stavanger, og sju av dem døde. Senere har vi hatt utbrudd i Østfold - i 2005 og i 2008. I 2005 ble 103 personer smittet, og ti døde. Dette er et av de største kjente utbrudd av legionærsykdom i verden.

Legionellabakterier forekommer i små mengder naturlig i vann og jord. Det er særlig når bakteriene får anledning til å formere seg i vann i tekniske installasjoner at de kan representere smittefare for mennesker. Smitten skjer ved inhalasjon av aerosoler eller partikler kontaminert med legionellabakterier. Legionella pneumophila er den hyppigste legionellaarten som er assosiert med sykdom hos mennesker. De siste ti årene har det vært meldt 21-48 tilfeller av legionellose årlig til Meldingssystem for smittsomme sykdommer (MSIS). Unntaket var 2005, da vi altså hadde et stort utbrudd i Norge.

Alle ferskvannanlegg kan representere en smitterisiko hvis det er tilgang på næringsstoffer og riktig temperatur for at legionellabakterien kan vokse. I dette nummer av Tidsskriftet beskrives en studie av forekomst av Legionella i fartøyer (1). Studien gir viktig kunnskap om forekomsten av Legionella i vannsystemer om bord på skip. I omtrent halvparten av de undersøkte fartøyene ble det påvist Legionella pneumophila i vannsystemet. Studien viste også at i fartøyer hvor bakterien ble påvist, ble det også påvist frittlevende amøber. Påvisning av amøber viser at det foreligger næringsforhold slik at legionellabakterien kan formere seg. Slike funn er viktig kunnskap for smitteforebygging.

Hensikten med forebygging av legionellasmitte er å hindre både enkelttilfeller og større utbrudd. Forholdende rundt store utbrudd av legionellose kan være komplekse, noe det som skjedde i Østfold viste. Der har både såkalte luftskrubber (en type renseanlegg for luft og gasser) og biologiske renseanlegg vært påvist som smittekilde $(2-5)$. Forebygging av legionellasmitte i tekniske anlegg er regulert i ulike lover og forskrifter. Kommunen skal ha oversikt over alle kjøletårn og luftskrubberanlegg og føre tilsyn med disse. Anleggseier har ansvar for å sørge for at anlegget ikke er smittefarlig. Det er viktig å vurdere om det er potensial for oppvekst av legionellabakterier og hvilke hendelser, f.eks. danning av aerosoler, som kan føre til at mennesker kan bli eksponert for bakteriene (6). Mikrobiologisk analyse er et supplement til kunnskap om tekniske og prosessmessige forhold som bidrar til at legionellabakterier kan formere seg eller spres. Resultater fra det aktuelle prosjektet, publisert i dette nummer av Tidsskriftet, bidrar til kunnskap om hvilke forebyggende tiltak som bør settes inn for å hindre at noen blir smittet av Legionella på skip (1).

Ved mistanke om legionellose kan flere diagnostiske mikrobiologiske metoder benyttes. Påvisning av legionellaantigen i urin er en hurtig og enkel metode, men den påviser kun sykdom med Legionella pneumophila serogruppe 1. Isolering av legionellabakterier fra klinisk prøvemateriale gir mulighet for arts- og typebestemmelse av bakteriene. Genetisk typing av bakteriene er nødvendig for å kunne påvise om flere er syke med samme bakterieisolat og for å kunne sammenlikne pasientisolat med miljøisolat fra mulige smittekilder (4). Flere laboratorier har tatt i bruk polymerasekjedereaksjon (PCR) for å påvise Legionella i ulike prøvematerialer. Metoden er hurtig og følsom.
I den aktuelle kartleggingsstudien av Legionella på sjøforsvarets fartøyer ble PCR brukt som screeningmetode. Positive prøver ble også dyrket (1). Ved å dyrke de PCR-positive prøvene får man informasjon om tilstedeværelse av levende legionellabakterier. Funn av samme genetiske bakterietype i vannsystem og bunkringsanlegg førte til at man konkluderte med at overføring av Legionella til fartøyenes vannsystem sannsynligvis skjedde via bunkringsanlegget.

Legionellose er en gruppe A-meldingspliktig sykdom, noe som betyr at tilfeller skal meldes både fra medisinsk-mikrobiologisk laboratorium og fra diagnostiserende lege til MSIS. Legionellose er også en varslingspliktig sykdom etter MSIS- og tubekuloseforskriften, dvs. at helsepersonell som har mistanke om at det foreligger et tilfelle av legionellose, umiddelbart skal varsle kommunelegen, som igjen varsler Fylkesmannen og Folkehelseinstituttet. Folkehelseinstituttet formidler informasjon om diagnostiserte tilfeller til det europeiske overvåkingsnettverket for legionellainfeksjoner (ELDSNet), som kan sammenholde denne informasjonen med informasjon fra andre land.

Legionellose er fremdeles en sjelden sykdom, og de fleste tilfellene er sporadiske. Utbruddene er sjeldne, men det er viktig med fortløpende kontroll, da sykdommen kan ha et alvorlig forløp med høy letalitet hos eldre og immunsvekkede.

Ingeborg S. Aaberge

ingeborg.aaberge@fhi.no

Ingeborg Sundsvalen Aaberge (f. 1952) er dr.med. og spesialist i medisinsk mikrobiologi og i immunologi og transfusjonsmedisin. Hun er avdelingsdirektør ved Avdeling for bakteriologi og infeksjonsimmunologi, Nasjonalt folkehelseinstitutt.

Forfatteren har fylt ut ICMJE-skjemaet og oppgir ingen interessekonflikter

\section{Litteratur}

. Ahlén C, Aas M, Nor A et al. Legionella pneumophila på Sjøforsvarets fartøyer Tidsskr Nor Legeforen 2013; 133: 1445-8.

2. Nygård K, Werner-Johansen $\emptyset$, Rønsen $\mathrm{S}$ et al. An outbreak of legionnaires disease caused by long-distance spread from an industrial air scrubber in Sarpsborg, Norway. Clin Infect Dis 2008; 46: 61-9.

3. Blatny JM, Reif BAP, Skogan G et al. Tracking airborne Legionella and Legio nella pneumophila at a biological treatment plant. Environ Sci Technol 2008; 42: $7360-7$.

4. Borgen K, Aaberge I, Werner-Johansen $\emptyset$ et al. A cluster of Legionnaires' disease linked to an industrial plant in southeast Norway, June-July 2008. Eurosurveill 2008; 13: 1-2.

5. Olsen JS, Aarskaug T, Thrane I et al. Alternative routes for dissemination of Legionella pneumophila causing three outbreaks in Norway. Environ Sci Technol 2010; 44: 8712-7.

6. Pettersen JE. Forebygging av legionellasmitte - en veiledning. 3. utg. Vannrapport 118. Oslo: Folkehelseinstituttet, 2012. www.fhi.no/eway/ default.aspx?pid=239\&trg=Content 6493\&Main_6157=6287:0:25,5499\&MainCon tent_6287=6493:0:25,6833\&Content_6493=6259:102022:0:6184:1:0:0 (1.7.2013). 